\title{
Investigation of the relationship among fantasy football participation motivation, consumer satisfaction and behavioral intentions
}

\author{
Oğuzhan DEMİRHAN ${ }^{1}$ Ersin ESKİLER ${ }^{2}$
}

\author{
${ }^{1}$ Sakarya University of Applied Sciences, Institute of Education Science, Physical Education and Sports PhD Student, Sakarya, Turkey. \\ ${ }^{2}$ Sakarya University of Applied Sciences, Faculty of Sport Science, Sports Management, Sakarya, Turkey. \\ Address correspondence to E, Eskiler, e-mail: eeskiler@gmail.com
}

\begin{abstract}
While consumer motivation is considered as a theoretical approach that explains how individuals choose to engage in various consumption behaviors at certain times, the theory of disapproval provides a common theoretical basis for exploring and explaining consumer satisfaction and consumer responses to consumption. As a matter of fact, it is important for the management to determine how the effect of motivation on consumer satisfaction and the future tendencies of individuals after consumption. In this context, the aim of the study was to reveal the motivation of participating individuals in the fantasy football and to investigate the relationship of motivation between, consumer satisfaction and behavioral intentions. The research was carried out by the survey model and the judgmental sampling method was used for sampling. The study population consisted of 509 active fantasy football participants in Turkey. The data were collected by an on-line survey method based on volunteerism. In order to determine participant characteristics, descriptive statistics and to identify the relationships between variables, correlation and regression analysis were used. The findings showed that there was a positive statistically significant relationship between fantasy football participation motivation (FFPM) subdimensions and consumer satisfaction and behavioral intention variables. As a result of the regression analysis, FFPM (subscales of entertainment, social interaction and gambling) could be predicted behavioral intent $\cong 36 \%(F=92.453, p$ $<0.01)$. On the other hand, behavioral intention could be explained by consumer satisfaction at $\cong \% 54(F=591.325, p<0.01)$. When both variables were included in the analysis, FFPM entertainment sub-dimension $(\beta=0.228)$ and consumer satisfaction $(\beta=0.604)$ could be clarified behavioral intentions by $57 \%(F(2,506)=340.236 ; p<0.01)$. In conclusion, it can be stated that FFPM and consumer satisfaction are important determinants of behavioral intentions separately and together.
\end{abstract}

Keywords: Sports, Fantasy football, Motivation, Satisfaction, Behavioral Intention

\section{INTRODUCTION}

Parallel to the technological developments, the concept of "online game" consumption has emerged as a result of the widespread use of the internet and the passive consumption of people through sports and the Internet (3). The ever-increasing number of online gamers (29) has led to an increase in the interest of sporting specialists and sports marketers in this market as well as being an industry all over the world $(35,15)$. In recent years, research into the economic and social consequences of online gaming / sports consumption has drawn attention. In this context, according to a report published in 2016, about 29 million people are interested in online games in Turkey. The revenue from these games is around $\$ 755$ million, of which $\$ 432$ million is from computer and console games, the rest from games played through mobile devices (26). One of the most widely played online games in the world today is fantasy sports. Fantasy sports; (24) is a game in which real players who are involved in many organizations such as football, basketball, tennis, ice hockey, car races are selected by virtual budgeting and teams are created and played online in order to earn points for the performance of the players in these teams based on their performance as a result of the competitions. Thus, the number of people who play daily fantasy sports games has been increased $(37,14,11)$. By 2017, the number of people who actively played fantasy sports in America and Canada has reached 59.3 million (25). In England, about 6 million people are interested in fantasy sports games. Although there is no clear information yet about the people who are interested in fantasy sports in Turkey, according to the results of a survey 
carried out in Europe (eg. Germany, France, Italy, Spain, Russia and Turkey, etc.); it has been determined that fantasy football players in Turkey have been playing fantasy football 2.2 hours per week (27).

\section{Fantasy Football Motivation, Consumer Satisfaction and Behavioral Intentions}

According to Ajzen (1), the realization of the behavior depends primarily on the formation of the intention towards that behavior. The stronger the intention towards behavior, the higher the probability of behavior. Oliver (34) describes the intention as the level of probability/possibility determined personally for the realization of a behavior. Researchers have emphasized that behavioral intentions are strong predictors of true behavior $(22,30)$ and an individual's behavior is predictable, based on the individual's intentions (2). In this context, behavioral intentions are considered as the determinants of consumer buying behavior in marketing literature and a large number of researchers in various sectors have examined the formation of behavioral intentions to better understand consumer consumption behavior. According to this; consumers can develop positive intentions such as positive verbal communication, repurchase, and making more purchases from the business, and vice versa. (4, 21, 31). Indeed, behavioral intentions are seen as a sign that consumers will continue to receive service from the organization or leave the organization (44). In recent years, in the literature of service marketing, there has been a variety of questions that determine what might be the determinants of behavioral intentions and it is observed that they focus on consumer satisfaction in these studies $(12,36,38)$. Satisfaction; is a affective process that expresses the combination of post-consumer thoughts of people's pre-consumer product or service $(33,42)$. Broderick and Pickton (9) stated that affective processes were the most important determinant of behavioral intentions with another expression of action. On the other hand, motivation is driven by motivations, and motives arise in line with people's needs and requirements. (32). Motives can be positive or negative. Positive motives are brought closer to events or objects, and negative motives are removed (17). In this context, it is important to determine the elements that direct fantasy football players to play this game, and the behavioral consequences of these elements. In this context the aim of the study was to reveal the participation motivation in the fantasy football game and to investigate the relationship among the motivation, consumer satisfaction and behavioral intentions. For this purpose, research hypotheses are as follows:

\section{H1: FFPM affects consumer satisfaction.}

H2: Consumer satisfaction affects behavioral intentions.

H3: FFPM influences behavioral intentions.

H4: There is an intermediary effect of consumer satisfaction in relation to FFPM and behavioral intentions.

\section{METHOD}

Based on quantitative research methods, a general survey model was used in this study. The survey method was used for obtaining the data, and was applied online to the participants.

In order to determine the level of participation motivation, "FFPM Scale" which was developed by Dwyer and Kim (14) in 2011 was used. The validity and reliability study of the scale was conducted by Eskiler, Demirhan and Soyer (16). The scale was based on a total of 17 expressions and 4 subscales (social interaction, gambling, competition, entertainment / escape). In the scale development study, Cronbach's alpha internal consistency coefficients of sub-dimensions were found to be in the range of .872-.794. In addition, as a result of the confirmatory factor analysis, the general fit-good index values for the model were determined to be within an acceptable range $\left(\chi^{2} / \mathrm{df}=1.36, \mathrm{CFI}=.96\right.$, $\mathrm{SRMR}=.06$, NNFI=.95, RMSEA=.006) and the structure was valid for measuring FFPM (14). To determine the satisfaction and behavioral intentions of the participants; 6 statements based on Oliver (33) and Zeithaml et al. (44) studies were included in the survey. In these studies, Cronbach's alpha internal consistency coefficient was determined as .82 and .94, respectively. In addition, the participant's demographic characteristics and personal information form related to determination of fantasy football participation status were included in the measurement tool. All expressions outside the personal information form were 7 points Likert type rating scales. Research universe was comprised of people who played fantasy football in Turkey. The sample of the research consisted of people who actively played fantasy football games and who accepted to participate in the research voluntarily. The judgmental sampling method was preferred in the selection of the sample. SPSS 22.0 package program was used to analyze the data. In addition to descriptive statistical, correlation and regression 
analysis were used to determine structural relationships between variables.

Fifty-nine questionnaires were used in the first stage and 509 questionnaires were used for analysis. It was determined that $91.9 \%$ of the participants included in the survey were male, $8.1 \%$ were female, and the average age of participants was $24.30 \pm 4.824$ and the average income was $1135.40 \pm 879.664$.

\section{FINDINGS}

In this section, the results of the analysis of the obtained data were presented.

Table 1. Descriptive Statistics

\begin{tabular}{|c|c|c|c|c|}
\hline \multicolumn{2}{|c|}{ Variables } & \multirow{2}{*}{$\begin{array}{c}X \\
5.35 \\
\end{array}$} & \multirow{2}{*}{$\begin{array}{c}\text { SS. } \\
1.454\end{array}$} & \multirow{2}{*}{$\begin{array}{c}\text { Cronbach's } \alpha \\
.885\end{array}$} \\
\hline \multirow{4}{*}{$\sum_{\frac{I}{I}}$} & Social Interaction & & & \\
\hline & Gambling & 3.55 & 1.809 & .895 \\
\hline & Competition & 5.74 & 1.138 & .831 \\
\hline & Entertainment & 5.72 & 1.039 & .802 \\
\hline \multicolumn{2}{|c|}{ Consumer Satisfaction } & 5.50 & 1.187 & .740 \\
\hline \multicolumn{2}{|c|}{ Behavioural Intention } & 5.46 & 1.394 & .854 \\
\hline
\end{tabular}

Note: Measurement level 7 Likert; $\mathrm{N}=509$

According to mean value of the sub-dimension scores of the fantasy football motivation scale $(\overline{\mathrm{X}}$ $=3.55 \pm 1.809)$, which was below the mean value of the gambling dimension and mean value of other dimensions were relatively close to the positive. The mean value of consumer satisfaction and behavioural intentions were; $\bar{X}=5.50 \pm 1.187$ and $\bar{X}=5.46 \pm 1.394$, respectively (Table 1). When descriptive statistics related to fantasy football motivation, consumer satisfaction and behavioural intentions were examined in general, it was determined that all variables were above acceptable ( $\alpha=70 \%$ ) confidence level (10) and when the skewness-kurtosis values of the obtained data were examined, all values were within \pm 2 value range (19) and the data showed normal distribution.

Table 2. Results of Correlation Analysis

\begin{tabular}{|c|c|c|c|c|c|c|c|}
\hline Variables & & 1 & 2 & 3 & 4 & 5 & 6 \\
\hline \multirow{2}{*}{ Social Interaction } & $\mathrm{r}$ & 1 & & & & & \\
\hline & $p$ & & & & & & \\
\hline \multirow{2}{*}{ Gambling } & $\mathrm{r}$ & $0.210^{* *}$ & 1 & & & & \\
\hline & $p$ & 0.000 & & & & & \\
\hline \multirow{2}{*}{ Competition } & $\mathrm{r}$ & $0.459^{* *}$ & $0.221^{* *}$ & 1 & & & \\
\hline & $\mathrm{p}$ & 0.000 & 0.000 & & & & \\
\hline \multirow{2}{*}{ Entertainment } & $\mathrm{r}$ & $0.456^{* *}$ & $0.222^{* *}$ & $0.667^{* *}$ & 1 & & \\
\hline & $\mathrm{p}$ & 0.000 & 0.000 & 0.000 & & & \\
\hline \multirow{2}{*}{$\begin{array}{l}\text { Consumer } \\
\text { Satisfaction }\end{array}$} & $\mathrm{r}$ & $0.448^{* *}$ & $0.239^{* *}$ & $0.445^{* *}$ & $0.569^{* *}$ & 1 & \\
\hline & $\mathrm{p}$ & 0.000 & 0.000 & 0.000 & 0.000 & & \\
\hline \multirow{2}{*}{$\begin{array}{l}\text { Behavioural } \\
\text { Intention }\end{array}$} & $\mathrm{r}$ & $0.391^{* *}$ & $0.220^{* *}$ & $0.436^{* *}$ & $0.572^{* *}$ & $0.734^{* *}$ & 1 \\
\hline & $\mathrm{p}$ & 0.000 & 0.000 & 0.000 & 0.000 & 0.000 & \\
\hline
\end{tabular}

As shown in Table 2, it was seen that there was a low, positive and statistically significant relationship between FFPM scale sub-dimensions. When the relationship between consumer satisfaction and FFKM scale sub-dimensions were investigated; consumer satisfaction and social interaction $(\mathrm{r}=.448 ; \mathrm{p}<.01)$; gambling $(\mathrm{r}=.239 ; \mathrm{p}<.01)$; there was a low positive correlation between competition $(\mathrm{r}=.445 ; \mathrm{p}<.01)$ and entertainment $(\mathrm{r}=.569 ; \quad \mathrm{p}<.01)$. Multiple regression analyses established between variables as summarized in Table 3.

First of all, FFPM had a statistically significant effect on consumer satisfaction (Model 1: $\mathrm{F}=76.685$, $\mathrm{p}=.000)$ and consumer satisfaction on behavioural intention (Model 2: $\mathrm{F}=591.347, \mathrm{p}=.000$ ). According to the findings, it can be stated that the first two hypotheses of the study were accepted. 
Table 3. Regression Analysis Results*

\begin{tabular}{|c|c|c|c|c|c|c|c|c|c|c|c|c|}
\hline \multirow{3}{*}{ Variables } & \multirow{2}{*}{\multicolumn{3}{|c|}{$\begin{array}{c}\text { Consumer Satisfaction } \\
\text { Model } 1\end{array}$}} & \multicolumn{9}{|c|}{ Behavioural Intention } \\
\hline & & & & \multicolumn{3}{|c|}{ Model 2} & \multicolumn{3}{|c|}{ Model 3} & \multicolumn{3}{|c|}{ Model 4} \\
\hline & $\beta$ & $t$ & $p$ & $\beta$ & $t$ & $p$ & $\beta$ & $t$ & $p$ & $\beta$ & $t$ & $p$ \\
\hline Constant & & 5.309 & 0.000 & & 3.606 & 0.000 & & 2.213 & .027 & & -1.055 & 0.292 \\
\hline Social Interaction & 0.217 & 5.318 & 0.000 & - & - & - & 0.144 & 3.466 & .001 & 0.015 & 0.437 & 0.662 \\
\hline Gambling & 0.091 & 2.489 & 0.013 & - & - & - & 0.078 & 2.103 & .036 & 0.024 & 0.797 & 0.426 \\
\hline Competition & 0.045 & 0.919 & 0.359 & - & - & - & 0.048 & 0.977 & .329 & 0.022 & 0.543 & 0.588 \\
\hline Entertainment & 0.421 & 8.658 & 0.000 & - & - & - & 0.457 & 9.236 & .000 & 0.207 & 4.804 & 0.000 \\
\hline Consumer Satisfaction & - & - & - & 0.734 & 24.317 & 0.000 & - & - & - & 0.594 & 16.093 & 0.000 \\
\hline $\mathbf{F}$ & & 76.685 & & & 591.347 & & & 69.573 & & & 135.948 & \\
\hline $\mathrm{R} 2$ & & 0.378 & & & 0.538 & & & 0.356 & & & 0.575 & \\
\hline Adjusted R2 & & 0.373 & & & 0.537 & & & 0.351 & & & 0.570 & \\
\hline
\end{tabular}

In the second phase; FFPM had a significant effect on behavioural intentions (Model 3: $\mathrm{F}=69.573$, $\mathrm{p}=.000)$. In this case, the condition proposed in the second phase (acceptance of hypothesis $\mathrm{H}_{3}$ ) was provided to determine the mediating effect. Finally; in the second phase, Model 4 was tested by adding consumer satisfaction to the model tested. It was seen that the effects of FFPM and consumer satisfaction on behavioural intentions were statistically significant (Model 4: $\mathrm{F}=135.948, \mathrm{p}=.000$ ). According to the findings obtained from the last model tested; it could be stated that consumer satisfaction had a partial mediating effect on the relationship between FFPM and behavioural intentions. In order to reveal the partial mediator effect clearly, the significance of the change in beta values was tested (23), and it was concluded that the value Sobel test statistic was significant in 95\% confidence interval.

\section{CONCLUSION \& RECOMMENDATIONS}

This research was conducted to examine the structural relationships between FFPM, consumer satisfaction and behavioural intentions. The findings showed that participants played a fantasy football game for competition, entertainment, social interaction and gambling, respectively. These results were consistency with the studies of Farquhar and Meeds (18) and Dwyer and Kim (14). When the relations between the structures were investigated, it was determined that consumer satisfaction was an important predictor of behavioural intentions. In addition, it was determined that consumer satisfaction had a partial mediation effect between

FFPM and behavioural intentions and motivation was an important priority of both satisfaction and behavioural intentions. In other words, motivation plays an active role on people's affective and behavioural processes. According to the findings, the effectiveness of the entertainment factor that motivates the participants to the game is particularly noteworthy. The entertainment dimension represents the escape of individuals from daily activities and the fun of following the games played in real life $(14,13)$.

A positive impact on the participants' perceptions of entertainment can be created by implementing different applications that will make the game more fun and providing fantasy football service providers with the simultaneous integration of the game with real competitions.

Another important motivation factor in the participation of the game is the motivation of social interaction; it represents the maintenance of relations with family, friends and / or colleagues or the establishment of relationships with new friends $(14,38)$

In this context, improving the in-game communication / interaction processes or implementing new applications can contribute to the development of consumer satisfaction and the development of behavioural loyalty.

On the other hand, the main expectation is that the motivation of gambling (6), which has more value than the risk, is another factor that has a positive effect on satisfaction and fantasy football participation. It can be stated that the compensation and unpredictability (7) among the distinguishing features of the sport phenomenon increase the effect of gambling motivation. Although competition is an important motivation factor for fantasy football participants, it has been determined that there is no statistically significant effect on consumer satisfaction and behavioural intentions. This result is inconsistent with the studies of Dvyer and Kim (14) and Farquhar and Meeds (18). However, past studies on general sports consumption motivation 
are examined $(42,41,43)$, it is observed that the competition dimension is not included in these studies. In this context, it is determined that fantasy football participants have similar characteristics with traditional sports consumers. In other words, it can be stated that fantasy football participants have the motivation of developing social relations, having fun and gambling rather than competition and shaping their satisfaction and behavioural intentions.

Armutlu and Üner (8) stated that consumer satisfaction was an important determinant of behavioural intentions, but only satisfaction in creating loyal consumers was not enough. The findings supported the importance of motivation as well as consumer satisfaction in order to increase and maintain the frequency and continuity of participation of fantasy football players. In other words, it is possible to say that research findings provide new gains in predicting and / or understanding future trends of fantasy football players. In addition, service providers should consider the positive relationships between FFPM and behavioural intentions. The findings demonstrated that motivation resources affected the re-participation of the game and recommending to others. This is an indication that service providers should focus more on the affective structures of the players in order to increase player loyalty.

Finally, satisfaction has been identified as an intermediary role between FFPM and behavioural intentions. It shows that service providers need a higher level of consumer satisfaction in order to achieve sustainable competitive advantage and to create positive player behaviour after purchase.

While studies on determining sports consumption and consumption demand increased in sports marketing (20, 41, 40, 39, 43); a limited number of studies in the national and international literature on fantasy sport consumption, which has shown significant development in recent years (14, 18). In this context, the study is expected to contribute to the development of new perspectives on fantasy sports and fantasy football consumption. The findings will help fantasy football service providers and sports marketers to develop effective market segmentation and promotion strategies.

This study has some limitations. The obtained data was collected by online survey and judgmental sampling method due to the limited knowledge of the population of the research. This situation complicates the generalizability of research results.
On the other hand, further research is needed to determine the relationship between fantasy football participation and traditional sports consumption behaviour.

\section{REFERENCES}

1. Ajzen I. The Theory of Planed Behavior. Organizational Behavior and Human Decision Processes.1991:50, 179-211.

2. Ajzen I, Fishbein M. Understanding attitudes and predicting social behavior. Englewood Cliffs, NJ: Prentice-Hall. 1980.

3. Alan KA. Kabadayı ET. Cavdar N. Why Do People Play Onlıne Games? The Role of Onlıne Gamer Innovatıveness. International Journal of Eurasia Social Sciences,2017:8(30), 2260-2280.

4. Ali F, Amin, M. The influence of physical environment on emotions, customer satisfaction and behavioural intentions in Chinese resort hotel industry. Journal for Global Business Advancement, 2014:7(3), 249-266.

5. Altunışık, R., Coşkun, R., Bayraktaroğlu, S, Yıldırım E. Sosyal Bilimlerde Araştırma Yöntemleri: SPSS Uygulamalı, Sakarya Kitabevi, Sakarya.2012.

6. Arcan K, Karanci AN. Kumar Oynama Nedenleri Ölçeğinin uyarlama, geçerlilik ve güvenilirlik çalışması. Anatolian Journal of Psychiatry/Anadolu Psikiyatri Dergisi, 2014:15(3), 248-256.

7. Argan M. Katırcı H. Spor Pazarlaması. Ankara: Nobel.2002.

8. Armutlu C, Üner MM. Benlik imajı uyumu, tüketici tatmini ve marka sadakati ilişkisi üzerine görgül bir araştırma. Gazi University Journal of Economics \& Administrative Sciences, 2009:11(3), 1-26.

9. Broderick A, Pickton D. Integrated marketing communications. Pearson Education UK. 2005.

10. Büyüköztürk Ş. Sosyal Bilimler için Veri Analizi El Kitabı. (22. Bask1) Ankara: Pegem Akademi.2016.

11. Comeau TO. Fantasy football participation and media usage. Doktora Tezi. Uni. of Missouri-Columbia. 2007.

12. Cronin JJ, Brady MK, Hult GTM. Assessing the effects of quality, value, and customer satisfaction on consumer behavioral intentions in service environments. Journal of retailing, 76(2), 193-218. 2000.

13. Dhurup M. Dlodlo N.To play or not to play! Online fantasy football consumption motives and the relationship with attitude and future behavioural intentions. Mediterranean J. of Soc. Sci. 2013: 4(14), 201.

14. Dwyer B, Kim Y. (2011). For love or money: Developing and validating a motivational scale for fantasy football participation. Journal of Sport Management, 25(1), 70-83.

15. Dwyer B, Shapiro SL, Drayer J. Segmenting motivation: An analysis of fantasy baseball motives and mediated sport consumption. Sport Marketing Quarterly, 2011:20, 129-137.

16. Eskiler E, Demirhan O, Soyer F. "Fantezi Futbol Katılım Motivasyonu Ölçeği" Türkçe Formu Geçerlik Ve Güvenirlik Çalışması. Beden Egitimi ve Spor Bilimleri Dergisi, 2017: 11(2), 159-169.

17. Evans M, Jamal A, Foxall G. Consumer Behaviour. England : Wiley Pablication.2010. 
18. Farquhar LK. Meeds R. Types of fantasy sports users and their motivations. Journal of Computer-Mediated Communication, 2007:12, 1208-1228

19. George D, P. Mallery. SPSS for Windows Step by Step: A Simple Guide and Reference 10.0 Update. 3. Bask1. Boston: Allyn and Bacon.2001.

20. Gültekin SG, Giray C. Bireylerin futbol taraftarı olmasın etkileyen güdüler ile sadakat arasındaki ilişki: Fenerbahçe taraftarları üzerine bir uygulama. Öneri. 2010:9(33), 89-97.

21. Han H, Kim W. Outcomes of relational benefits: restauran customers' perspective, Journal of Travel \& Tourism Marketing, 2009:26(8), 820-835.

22. Han H, Ryu K.The roles of the physical environment, price perception, and customer satisfaction in determining customer loyalty in the restaurant industry. Journal of Hospitality \& Tourism Research, 2009:33(4), 487-510.

23. Hayes AF. Introduction to mediation, moderation, and conditional process analysis. New York: Guilford Press.2013.

24. http://money.cnn.com/2015/10/06/news/companies/fantasysports-101/index.html (URL1).

25. https://fsta.org/research/industry-demographics/ (URL2)

26. https://www.gaminginturkey.com/en/turkish-game-market$\underline{2016}$ (URL4)

27. https://www.sportbusiness.com/global-sports-mediaconsumption-report (URL3)

28. Kalaycı Ş. SPSS uygulamalı çok değişkenli istatistik teknikleri. Ankara: Asil Yayın Dağıtım.2014.

29. Kim EJ, Namkoong $\mathrm{K}, \mathrm{Ku} \mathrm{T}$, Kim, SJ. The relationship between online game addiction and aggression, self-control and narcissistic personality traits. European psychiatry, 2008:23(3), 212-218.

30. Kwon HH, Trail G, James JD. The mediating role of perceived value: Team identification and purchase intention of teamlicensed apparel. Journal of Sport Management, 2007:21(4), 540-554.

31. Ladhari R. Service quality, emotional satisfaction, and behavioural intentions: A study in the hotel industry. Managing Service Quality: An International Journal, 2009:19(3), 308-331.

32. Luthans F. Organizational behavior. McGraw-Hill International Edition.2005.

33. Oliver RL. A Cognitive Model of the Antecedents and Consequences of Satisfaction Decisions. Journal of Marketing Research. 1980:17, 460-469.

34. Oliver RL. Satisfaction: A Behavioral Perspective on the Consumer. 2. Bask1. New York: Sharpe, Inc.1997.

35. Ruihley BJ. The Fantasy Sport Experience: Motivations, Satisfaction, and Future İntentions. Doktora tezi, Tennessee Üniversitesi.2010.

36. Severt D, Wang Y, Chen PJ, Breiter D. Examining the Motivation, Perceived Performance, and Behavioral Intentions of Convention Attendees: Evidence from A Regional Conference. Tourism Management, 2007:28(2), 399408 .
37. Shipman FM. Blending the real and virtual: Activity and spectatorship in fantasy sports. The Conference on Digital Arts and Culture. Retrieved on April (Say1. 8, p. 2007).

38. Spinda JSW. Haridakis PM. Exploring the motives of fantasy sports: A use-and gratifications approach. In L.W. Hugenberg, P.M. Haridakis, \& A.C. Earnheardt (Eds.), Sports mania: Essays on fandom and the media in the 21st century, 2008:187-199

39. Tok S. Spor tüketimi davranışını etkileyen motivasyonel faktörler ve spor tüketimi motivasyon ölçeğinin Türkçeye uyarlanması. Yayınlanmamış Doktora Tezi. İzmir: Ege Üniversitesi.2004

40. Trail GT, James JD. The motivation scale for sport consumption: Assessment of the scale's psychometric properties. Journal of Sport Behavior, 2001:24, 108-127

41. Trail GT, Anderson DF, Fink J. A theoretical model of sport fan consumption behavior. International Journal of Sport Management, 2000: 3, 154-180.

42. Vavra T. "Selling after the sale", Bank Marketing, 1995:27 (1) $27-30$

43. Wann DL. Preliminary validation of the sport fan motivation scale. International Journal of Sport Psychology, 1995: 24, 117.

44. Zeithaml VA, Berry LL, Parasuraman A. The Behavioral Consequences of Service Quality. The Journal of Marketing, 1996:31-46.

* The Durbin-Watson coefficient values for all regression models were investigated to determine whether there were multiple connections in the data pattern. Bilateral correlations were found to be less than 0.80 , the tolerance values were greater than 0.20 , the variance magnification factor was less than 10, and the highest status index (CI) was less than 30, and there was no auto correlation problem between the variables (Altunışık et al. , 2012; Büyüköztürk, 2016; Kalayct, 2014),(Table 3). 